\title{
PENGARUH BEBERAPA EKSTRAK TANAMAN OBAT TERHADAP PERTUMBUHAN KOLONI DAN PRODUKSI SPORA $C$. gloeosporioides PENYEBAB PENYAKIT ANTRAKNOSA PADA CABAI (Capsicum annuum L)
}

\section{THE EFFECT OF SOME PLANT EXTRACTS ON THE HYPHAE GROWTH AND SPORE PRODUCTION C. gloeosporioides CAUSES OF DISEASE ANTRACNOSE ON CHILI (Capsicum annuum L)}

\author{
Zakiah Selviani", Efri, Ivayani, \& Radix Suharjo \\ Jurusan Agroteknologi, Fakultas Pertanian, Universitas Lampung \\ Jl Sumantri Brojonegoro 1, Bandar Lampung 35145, Indonesia \\ *Email:selvianizakiah@gmail.com
}

\begin{abstract}
Vegetable fungicides are substances derived from plants that have the potential to inhibit and kill pathogenic fungi. Compounds contained in medicinal plants such as alkaloid phytochemical compounds, saponins, flavonoids, tannins, polyphenols, essential oils, and steroids have the potential to be vegetable fungicides. This study aims to determine the effect of several medicinal plant extracts on the hyphae growth and production of pathogenic spores in vitro. The treatments in this study were arranged in a randomized block design (RBD) using 11 treatments with four replications. The treatments consisted of control, Senna alata (ketepeng) fraction, Vernonia amygdalina (African leaf) fraction, Pluchea indica (beluntas)fraction, Cyperus rotundus (rumput teki) fraction, Andrographis paniculata (sambiloto) fraction, fresh ketepeng extract, fresh African leaf extract, fresh beluntas extract, fresh rumput teki extract, and fresh sambiloto extract. The data obtained were tested for homogeneity of variety and additivity using the Tukey test. Then the data were analyzed by analysis of variance and continued with the LSD test at the $5 \%$ level. The results showed that overall the treatment had no significant effect in suppressing the hyphae growth and spore growth of $C$. gloeosporioides. However, the fractions that were able to suppress the production of $C$. gloeosporioides spores were the treatment of the ketepeng fraction, the African leaf fraction, the beluntas fraction, the rumput teki fraction, the sambiloto fraction, the fresh extract of ketepeng, the fresh extract of African leaves, the fresh extract of beluntas, and the fresh extract of sambiloto.
\end{abstract}

Keywords: C. gloeosporioides, fraction, medicinal plants

\begin{abstract}
ABSTRAK
Fungisida nabati merupakan zat yang berasal dari tanaman yang berpotensi menghambat dan mematikan jamur patogen. Senyawa yang terkandung dalam tanaman obat seperti senyawa fitokimia alkaloid, saponin, flavonoid, tanin, polifenol, minyak atsiri, dan steroid yang berpotensi sebagai fungisida nabati. Penelitian bertujuan untuk mengetahui pengaruh beberapa ekstrak tanaman obat terhadap pertumbuhan dan produksi spora patogen secara In vitro. Perlakuan dalam penelitian ini disusun dalam RancanganAcak Kelompok (RAK) menggunakan 11 perlakuan dengan empat ulangan. Perlakuan terdiri dari kontrol, fraksi ketepeng, fraksi daun afrika, fraksi beluntas, fraksi teki, fraksi sambiloto, ekstrak segar ketepeng, ekstrak segar daun afrika, ekstrak segar beluntas, ekstrak segar teki, dan ekstrak segar sambiloto. Data yang diperoleh diuji homogenitas ragam dan aditivitas
\end{abstract}


dengan uji Tukey kemudian data dianalisis dengan analisis ragam dan dilanjutkan dengan uji BNJ pada taraf $5 \%$. Hasil penelitian menunjukkan bahwa secara keseluruhan perlakuan tidak berpengaruh nyata dalam menekan pertumbuhan dan kecepatan tumbuh C. gloeosporioides. Namun fraksi yang mampu menekan produksi jumlah spora C. Gloeosporioides yaitu perlakuan fraksi ketepeng, fraksi daun afrika, fraksi beluntas, fraksi teki, fraksi sambiloto, ekstrak segar ketepeng, ekstrak segar daun afrika, ekstrak segar beluntas, dan ekstrak segar sambiloto.

Kata kunci: C. gloeosporioides, Fraksi, Tanaman obat

\section{PENDAHULUAN}

Cabai (Capsicum annum L.) merupakan salah satu komoditas sayuran yang tidak dapat ditinggalkan dalam kehidupan sehari-hari. Komoditas ini berguna sebagai penyedap masakan dan pembangkit selera makan, cabai juga mengandung zat-zat gizi yang sangat diperlukan untuk kesehatan manusia. Cabai besar memiliki kontribusi dengan produksi sebesar 1.210.000 ton atau sekitar 9,02 persen dari produksi sayuran nasional dan berada pada urutan keempat (BPS, 2017).

Penyakit Antraknosa adalah salah satu kendala ekonomi utama untuk produksi cabai di seluruh dunia, terutama di daerah tropis dan subtropis. Informasi taksonomi yang akurat diperlukan untuk manajemen pengendalian penyakit yang efektif(Than dkk., 2008). Menurut Piay dkk. (2010) bahwa penyakit antraknosa disebabkan oleh jenis jamur patogen Colletotrichum capsici dan Colletotrichum. gloeosporioides. Colletotrichum adalah genus besar jamur Ascomycete, yang mengandung spesies yang menyebabkan penyakit antraknosa pada berbagai tanaman bernilai ekonomi (Moe dan Keun, 2016). Genus Colletotrichum dapat menyebabkan gejala pada biji berupa kegagalan berkecambah dan mengakibatkan layu semai. Gejala pada buah cabai dapat terlihat bercak kecil, pada kerusakan parah dapat menyebabkan nekrosis dan bercak pada daun. Pada tanaman yang dewasa akan menyebabkan mati pucuk pada daun, batang, dan buah. Penyakit antraknosa berkembang ketika curah hujan tinggi dan dapat menyebabkan kerusakan buah mencapai 84\% (Nayaka dkk., 2009).

Beberapa upaya pengendalian yang dilakukan untuk mencegah penyakit antraknosa pada cabai meliputi penggunaan varietas tahan, secara kultur teknis, secara mekanis dan kimiawi. Adapun langkah pencegahan yaitu melalui sanitasi lahan, penggunaan benih berkualitas, dan penggunaan fungisida sebelum serangan terjadi sangat membantu penurunan itensitas serangan penyakit. Salah satu teknik pengendalian yang ramah terhadap lingkungan yaitu menggunakan fungisida nabati.

Penggunaan fungisida nabati merupakan salah satu alternatif pengendalian yang aman untuk digunakan secara berkelanjutan. Penggunaan fungisida nabati selain dapat mengurangi pencemaran lingkungan, harganyapun relatif lebih murah apabila dibandingkan dengan fungisida sintetis. Penelitian ini bertujuan untuk mengetahui pengaruh beberapa ekstrak tanaman obat terhadap pertumbuhan, kecepatan tumbuh dan produksi spora patogen secara in vitro. 


\section{BAHAN DAN METODE}

Penelitian ini dilaksanakan di Laboratorium Penyakit Tumbuhan dan Laboratorium Bioteknologi Fakultas Pertanian Universitas Lampung pada bulan September- Oktober 2018. Perlakuan disusun dalam rancangan acak kelompok (RAK) dengan 11 perlakuan yang masing-masing diulang sebanyak empat kali. Masing-masing perlakuan diberi fraksi ekstrak tanaman obat dengan konsentrasi 3000 ppm. Data yang diperoleh diuji homogenitas ragam dan aditivitasnya dengan uji tukey kemudian data dianalisis dengan analisis ragam dan diuji lanjut dengan uji BNJ pada taraf $5 \%$. Dalam penelitian pengujian menggunakan metode umpan beracun (Poison Food Technique) dengan menumbuhkan C. gloeosporioides pada media yang telah dicampurkan dengan pestisida nabati sesuai dengan perlakuan. Parameter pengamatan yaitu diameter koloni C. gloeosporioides, kecepatan tumbuh koloni C. gloeosporioides dan produksi spora C. gloeosporioides.

Diameter koloni C. gloeosporioides dihitung dengan rumus sebagai berikut (Achmad dan Suryana, 2009).

$$
D=\frac{d 1+d 2+d 3+d 4}{4}
$$

Keterangan: $\mathrm{d} 1, \mathrm{~d} 2, \mathrm{~d} 3, \mathrm{~d} 4$ : diameter koloni $C$. gloeosporioides hasil pengukuran dari empat arah yang berbeda

Kecepatan tumbuh C. gloeosporioides diukur berdasarkan diameter koloni, hasil pengukuran kemudian dikurang dengan dimeter pengamatan dihari sebelumnya. Dengan rumus

\section{Kecepatan tumbuh $=$ D2-D1}

Keterangan :

D1: Diameter awal

D2: Diameter hari berikutnya

Penghitungan kerapatan jumlah spora $C$. gloeosporioides. Rumus kerapatan spora menurut Sudibyo (1994) dalam Surtikanti \& Juniarsih (2010).

\section{$K=$ jumlah spora $x 2,5 \times 10^{5}$}

Keterangan :

K : Kerapatan spora $/ \mathrm{ml}$

2,5 : Konstanta atau faktor koreksi penggunaan kotak sampel pada haemocytometer

\section{HASIL DAN PEMBAHASAN}

\section{Kemampuan Penghambatan Ekstrak Tanaman}

\section{Obat terhadap Pertumbuhan}

C. gloeosporioides. Penghambatan pertumbuhan C. gloeosporioides diukur berdasarkan diameter koloni yang dibandingkan dengan kontrol, bila diameter koloni lebih kecil dari kontrol berarti mengalami penghambatan. Hasil analisis ragam pengaruh ekstrak tanaman obat terhadap pertumbuhan C. gloeosporioides 3 dan 4 hsi (hari setelah isolasi) menunjukkan berpengaruh nyata. Jika dibandingkan dengan kontrol semua perlakuan tidak menunjukkan perbedaan yang nyata. Pengaruh perlakuan yang menunjukkan perbedaan yang nyata hanya antara fraksi beluntas, fraksi teki dan ekstrak segar beluntas. Dengan demikian secara keseluruhan semua perlakuan tidak menunjukkan pengaruh yang nyata, akan tetapi bila dilihat dari nilai rata-rata diameter koloni fraksi teki menunjukkan 
nilai yang kecil, bahkan lebih kecil dari kontrol dan ini menunnjukkan teki memiliki potensi menghambat C. Gloeosporioides (Tabel 1, Gambar 1 dan 2).

Kecepatan Tumbuh $C$. gloeosporioides. Hasil analisis ragam ekstrak tanaman obat terhadap kecepatan tumbuh $C$. gloeosporioides tidak berpengaruh nyata (Tabel 2). Namun bila dilihat dari rata-rata kecepatan tumbuh, ekstrak tanaman ini berpotensi menghambat pertumbuhan $C$. Gloeosporioides koloni pada kontrol cenderung lebih cepat. Hal tersebut terlihat dari pengamatan 7 hsi, yang menunjukkan bahwa kecepatan tumbuh perlakuan kontrol lebih cepat dibandingkan dengan tanaman obat (Gambar 3).

Produksi Spora C. gloeosporioides. Hasil pengamatan terhadap pengaruh ekstrak tanaman obat

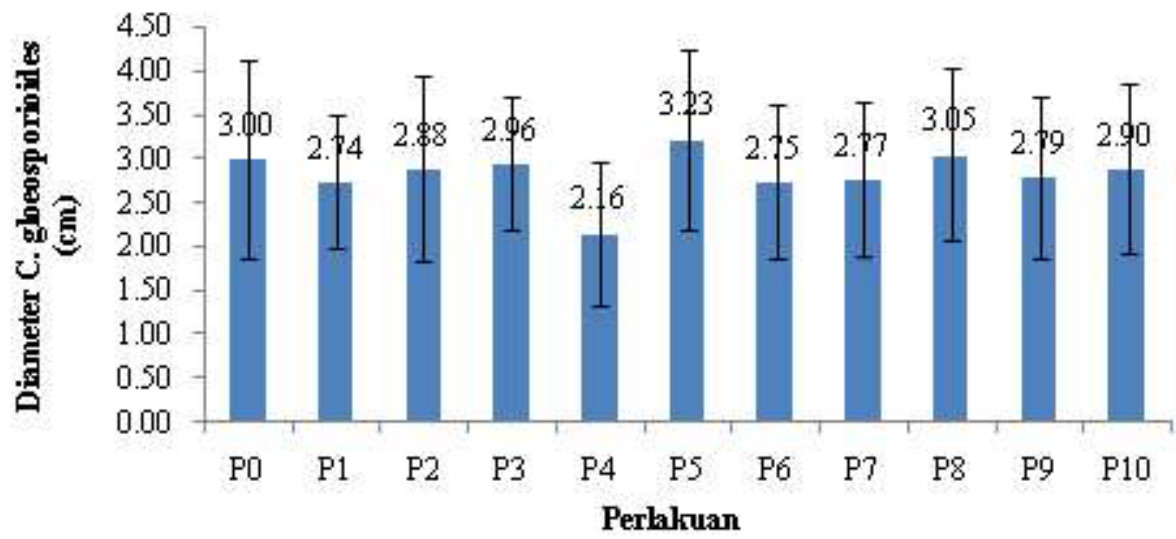

Gambar 1. Diagram pengaruh perlakuan beberapa ekstrak tanaman obat terhadap diameter koloni C. gloeosporioides pada $7 \mathrm{hsi}$

Keterangan: $\mathrm{P} 0=$ Kontrol, $\mathrm{P} 1=$ Fraksi ketepeng, $\mathrm{P} 2=$ Fraksi daun afrika, $\mathrm{P} 3=$ Fraksi beluntas, $\mathrm{P} 4=$ Fraksi teki, $\mathrm{P} 5=$ Fraksi sambiloto, $\mathrm{P} 6=$ Ekstrak segar ketepeng, $\mathrm{P} 7=$ Ekstrak segar daun afrika, $\mathrm{P} 8=$ Ekstrak segar beluntas, $\mathrm{P} 9=$ Ekstrak segar teki, P10 = Ekstrak segar sambiloto

Tabel 1. Data hasil sidik ragam pengujian beberapa fraksi ekstak tanaman obat terhadap panjang diameter C. gloeosporioides pada pengamatan $3 \mathrm{hsi}-7 \mathrm{hsi}$.

\begin{tabular}{lccccc}
\hline \multirow{2}{*}{ Perlakuan } & \multicolumn{5}{c}{ Koloni $\boldsymbol{C}$. gloeosporioides(cm) } \\
\cline { 2 - 6 } & $\mathbf{3 ~ h s i}$ & $\mathbf{4 ~ h s i}$ & $\mathbf{5 ~ h s i}$ & $\mathbf{6 ~ h s i}$ & $\mathbf{7 ~ h s i}$ \\
\hline Kontrol & $1,57 \mathrm{ab}$ & $2,29 \mathrm{ab}$ & 2,99 & 3,73 & 4,44 \\
Fraksi Ketepeng & $1,82 \mathrm{ab}$ & $2,29 \mathrm{ab}$ & 2,61 & 3,34 & 3,66 \\
Fraksi Daun Afrika & $1,55 \mathrm{ab}$ & $2,19 \mathrm{ab}$ & 2,90 & 3,61 & 4,17 \\
Fraksi Beluntas & $1,96 \mathrm{a}$ & $2,46 \mathrm{a}$ & 3,09 & 3,44 & 3,85 \\
Fraksi Teki & $1,13 \mathrm{~b}$ & $1,57 \mathrm{~b}$ & 2,33 & 2,61 & 3,16 \\
Fraksi Sambiloto & $1,97 \mathrm{a}$ & $2,51 \mathrm{a}$ & 3,26 & 3,92 & 4,50 \\
S. Ketepeng & $1,73 \mathrm{ab}$ & $2,05 \mathrm{ab}$ & 2,79 & 3,29 & 3,88 \\
S. Daun Afrika & $1,64 \mathrm{ab}$ & $2,15 \mathrm{ab}$ & 2,88 & 3,38 & 3,79 \\
S. Beluntas & $1,91 \mathrm{a}$ & $2,39 \mathrm{ab}$ & 2,87 & 3,83 & 4,26 \\
S. Teki & $1,79 \mathrm{ab}$ & $2,04 \mathrm{ab}$ & 2,76 & 3,36 & 4,01 \\
S. Sambiloto & $1,70 \mathrm{ab}$ & $2,19 \mathrm{ab}$ & 2,98 & 3,56 & 4,06 \\
\hline \multicolumn{1}{c}{ F hitung } & $2,77^{*}$ & $2,34^{*}$ & $1,30 \mathrm{tn}$ & $2,09 \mathrm{tn}$ & $1,94 \mathrm{tn}$ \\
\multicolumn{1}{c}{ F tabel } & 2,16 & 2,16 & 2,16 & 2,16 & 2,16 \\
\hline
\end{tabular}




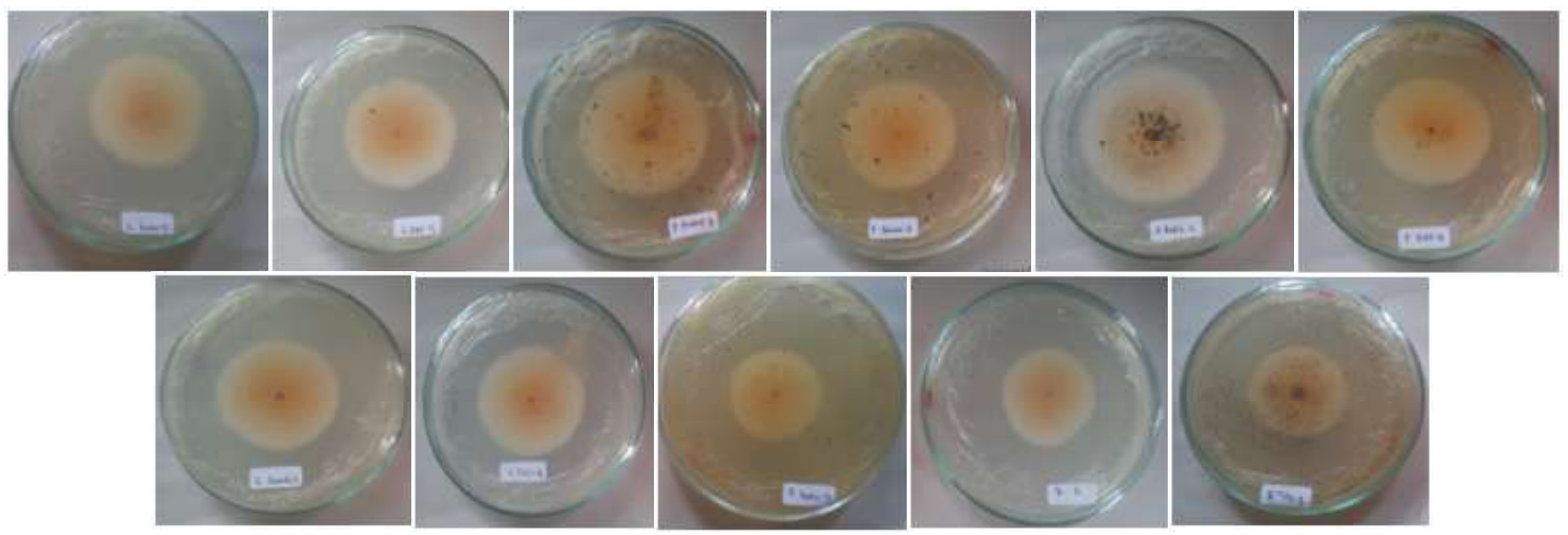

Gambar 2. Hasil uji in vitro beberapa ekstrak tanaman obat terhadap daya hambat pertumbuhan patogen penyebab penyakit antraknosa: a.Ekstrak segar beluntas, b. Ekstrak segar daun afrika, c. Fraksi ketepeng, d. Fraksi sambiloto, e. Ekstrak segar ketepeng, f. Fraksi daun afrika, g. Ekstrak segar sambiloto, h. Ekstrak segar teki, i. Fraksi beluntas, j. Kontrol, k. Fraksi teki

Tabel 2. Data nilai tengah pengujian beberapa fraksi ekstrak tanaman obat terhadap kecepatan tumbuh C. gloeosporioides pada pengamatan $3 \mathrm{hsi}-7 \mathrm{hsi}$.

\begin{tabular}{lccccc}
\hline \multirow{2}{*}{ Perlakuan } & \multicolumn{5}{c}{ KecepatanTumbuh C. gloeosporioides(cm/hari) } \\
\cline { 2 - 6 } & $\mathbf{3 ~ h s i}$ & $\mathbf{4 ~ h s i}$ & $\mathbf{5 ~ h s i}$ & $\mathbf{6 ~ h s i}$ & $\mathbf{7 ~ h s i}$ \\
\hline Kontrol & 0,84 & 0,73 & 0,69 & 0,74 & 0,71 \\
Fraksi Ketepeng & 1,00 & 0,47 & 0,33 & 0,73 & 0,33 \\
Fraksi Daun Afrika & 0,96 & 0,64 & 0,71 & 0,71 & 0,56 \\
Fraksi Beluntas & 1,09 & 0,50 & 0,64 & 0,34 & 0,41 \\
Fraksi Teki & 0,71 & 0,44 & 0,76 & 0,28 & 0,55 \\
Fraksi Sambiloto & 1,14 & 0,54 & 0,75 & 0,66 & 0,58 \\
S. Ketepeng & 1,06 & 0,33 & 0,74 & 0,49 & 0,59 \\
S. Daun Afrika & 0,93 & 0,51 & 0,73 & 0,50 & 0,41 \\
S. Beluntas & 1,06 & 0,48 & 0,48 & 0,96 & 0,43 \\
S. Teki & 1,19 & 0,25 & 0,72 & 0,61 & 0,64 \\
S. Sambiloto & 0,95 & 0,49 & 0,79 & 0,58 & 0,50 \\
\hline \multicolumn{1}{c}{ F hitung } & 1,75 tn & 1,22 tn & 0,92 tn & 0,95 tn & 1,46 tn \\
\hline
\end{tabular}

terhadap produksi jumlah spora C. gloeosporioides (Tabel 3). Berdasarkan Tabel 3 dapat dijelaskan bahwa pengaruh ekstrak tanaman obat terhadap produksi spora berpengaruh nyata, semua perlakuan menunjukkan pengaruh yang berbeda nyata dengan kontrol kecuali pada perlakuan ekstrak segar teki. Dengan demikian perlakuan beberapa ekstrak tanaman obat mampu menekan produksi jumlah spora kecuali pada perlakuan ekstrak segar teki. Berdasarkan hasil analisis data di atas, ternyata ekstrak tanaman obat ini walaupun tidak bisa menekan secara nyata pertumbuhan vegetatifjamur (diameter koloni) tapi dia bisa menekan produksi jumlah spora. Dengan demikian sifat cara kerja dari bahan aktif ekstrak tanaman obat ini adalah dengan menghambat sporulasi atau antisporulan.

Antisporulan adalah zat kimia yang mengurangi atau menghalangi produksi spora tanpa menghentikan 


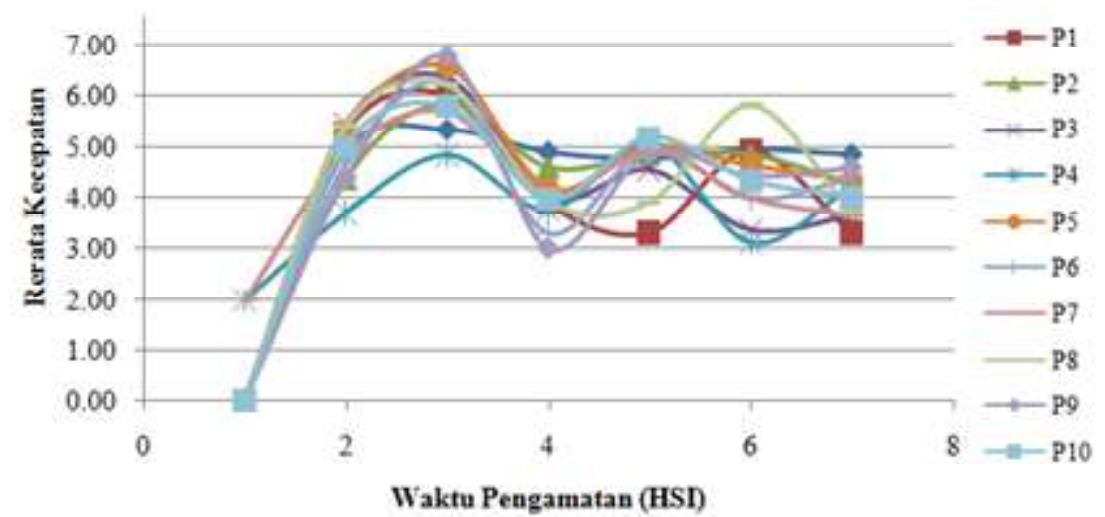

Gambar 3. Diagram pengarun perlakuan beberapa ekstrak tanaman obat ternadap kecepatan tumbuh C. gloeosporioides dari 1-7 hsi. (Keterangan: $\mathrm{P} 0=$ Kontrol, $\mathrm{P} 1=$ Fraksi ketepeng, $\mathrm{P} 2=$ Fraksi daun afrika, P3 = Fraksi beluntas, P4 = Fraksi teki, P5 = Fraksi sambiloto, P6= Ekstrak segar ketepeng, P7 = Ekstrak segar daun afrika, P8 = Ekstrak segar beluntas, P9 = Ekstrak segar teki, P10 = Ekstrak segar sambiloto).

perkembangbiakan vegetatifnya (Novel, 2010).

Menurut Asmaliyah dkk. (2010) beberapa jenis tumbuhan yang berpotensi sebagai fungisida yang didalamnya terkandung saponin, flavonoid, tanin, polifenol, minyak atsiri, dan steroid. Reaksi pertubuhan C. gloeosporioides yang ditunjukkan oleh perlakuan fraksi ketepeng, fraksi daun afrika dan fraksi

Tabel 3. Data hasil sidik ragam pengujian beberapa fraksi ekstak tanaman obat terhadap produksi jumlah spora C. gloeosporioides pada pengenceran $10^{2}$

\begin{tabular}{lc}
\hline \multicolumn{1}{c}{ Peralakuan } & $\begin{array}{c}\text { Jumlah Spora } C . \\
\text { gloeosporioides }\end{array}$ \\
\hline Kontrol & $6,875 \times 10^{7} \mathrm{a}$ \\
Fraksi Ketepeng & $0,625 \times 10^{7} \mathrm{c}$ \\
Fraksi Daun Afrika & $0,625 \times 10^{7} \mathrm{c}$ \\
Fraksi Beluntas & $1,25 \times 10^{7} \mathrm{bc}$ \\
Fraksi Teki & $2,5 \times 10^{7} \mathrm{bc}$ \\
Fraksi Sambiloto & $0 \mathrm{c}$ \\
S. Ketepeng & $1,25 \times 10^{7} \mathrm{bc}$ \\
S. Daun Afrika & $1,25 \times 10^{7} \mathrm{bc}$ \\
S. Beluntas & $1,875 \times 10^{7} \mathrm{bc}$ \\
S. Teki & $5 \times 10^{7} \mathrm{ab}$ \\
S. Sambiloto & $1,875 \times 10^{7} \mathrm{bc}$ \\
\hline fhitung & $6,80^{*}$ \\
f tabel & 2,16 \\
BNJ 5\% & 3,88 \\
\hline
\end{tabular}

sambiloto fraksi ketepeng, fraksi daun afrika, fraksi beluntas, fraksi teki, fraksi sambiloto, ekstrak segar ketepeng, ekstrak segar daun afrika, ekstrak segar beluntas, dan ekstrak segar sambiloto tersebut diduga karena adanya senyawa aktif seperti saponin, alkaloid, flavonoid, tanin yang terlarut dalam fraksi ketepeng, fraksi daun afrika dan fraksi sambiloto.

Saponin dan flavonoid dapat membentuk kompleks dengan protein ekstra seluler dan juga dinding sel jamur sehingga menyebabkan membran sel jamur terganggu (Soetan dkk., 2006). Menurut Ridawati dkk. (2011) Senyawa alkaloid mampu merusak membran sel dengan cara mendenaturasi protein sehingga membran sel lisis dan mati, sedangkan tanin akan bereaksi dengan lipid dan asam amino yang terdapat pada dinding sel jamur sehingga dinding sel akan rusak dan tanin akan masuk ke dalam inti sel jamur. Senyawa tanin yang masuk ke dalam inti sel akan bereaksi dengan struktur lipid dari DNA inti sel jamur yang menyebabkan inti sel lisis dan mati (Jawetz dkk., 2005). 
Ektrak segar tanaman obat teki (C. rotundus), belum mampu menekan pertumbuhan dan produksi jumlah spora patogen $C$. gloeosporioides, walaupun tanaman obat tersebut mengandung senyawa kimia saponin, kumarin, asam fenolat, lignan, terpen, luteolin dan flavonoid. Hal tersebut kemungkinan dikarenakan konsentrasi yang dipakai terlalu kecil (3000 ppm) sehingga tidak mampumenekan pertumbuhan dan produksi jumlah spora $C$. gloeosporioides.

\section{KESIMPULAN}

Berdasarkan hasil penelitian dapat disimpulkan bahwa semua ekstrak tanaman obat 3000 ppm tidak dapat menghambat pertumbuhan C. gloeosporioides. Semua ekstrak tanaman obat 3000 ppm tidak dapat menghambat kecepatan tumbuh C. gloeosporioides. Perlakuan fraksi ketepeng, fraksi daun afrika, fraksi beluntas, fraksi teki, fraksi sambiloto, ekstrak segar ketepeng, ekstrak segar daun afrika, ekstrak segar beluntas, dan ekstrak segar sambiloto mampu menekan produksi jumlah spora C. gloeosporioides.

\section{DAFTAR PUSTAKA}

Achmad \& Suryana I. 2009. Pengujian aktivitas ekstrak daun sirih (Piper betle Linn.) secara in vitro. Buletin Littro. 20(1):92-98.

Asmaliyah, Wati E. E. H, Utami S., Mulyadi K., Yudhistira, \& Sari F.W. 2010. Pengenalan Tumbuhan Penghasil Pestisida Nabati dan Pemanfaatannya secara Tradisional. Badan Penelitian dan Pengembangan Kehutanan. Palembang. $58 \mathrm{hlm}$.
Badan Pusat Statistik (BPS). 2017. Statistik Tanaman Sayuran dan Buah-Buahan Semusim Indonesia 19932016. https:// www.bps.go.id/linkTableDinamis /view/id/ 868. Diakses pada 10 Mei 2019.

Jawetz, Melnick, \& Adelberg. 2005. Mikrobiologi Kedokteran. Edisi I. Diterjemahkan oleh Penerjemah Bagian Mikrobiologi Fakultas Kedokteran Universitas Airlangga. Surabaya.

Moe M, \& Keun S. 2016. Chilli antracnose (Colletotrichum spp.) disease and its management approach. KJOAS. 43(2): 153-162.

Nayaka C.S, Shankar U.C.A, Niranjana S.R, Prakash.H.S, \& Mortensen.N.C. 2009. Antaknose Disease Of Chili Pepper. Technical Bulletin. 4(4):1-13.

Novel S.S. 2010. Kamus Biologi SMA. Gagas Media. Jakarta. $546 \mathrm{hlm}$.

Piay S, Tyasdjaja A, Ermawati dan Hantoro F. 2010. Budidaya dan Pasca Panen Cabai Merah(Capsicum annum L). BP3BTP. Ungaran. $60 \mathrm{hlm}$.

Ridawati, Jenie B.S.L, Djuwita I, \& Sjamsuridzal W. 2011. Aktivitas antifungal minyak atsiri jinten putih terhadap Candida parapsilosis SS25, C. orthopsilosis NN14, C. metapsilosis MP27, \& C. etchellsii MP18. Makara Sains. 15(1):58-62.

Soetan K.O, Oyekunle M.A, Aiyelaagbe O, \& Fafunso M.A. 2006. Evaluation of the antimicrobial activity of saponins extract of Shorgum bicolor L. Moench. Afr. J. Biotechnol. 5(23):2405-2407 
Surtikanti \& Juniarsih. 2010. Pembuatan Formula Pestisida Hayati Beauveria bassiana Vuill dan kemasannya. Balai Penelitian Tanaman Serealia. Maros $79 \mathrm{hlm}$.
Than P.P, Prihastuti H, Phoulivong S, Taylor P.W.J, \& Hyde K.D. 2008. Chili antracnose disease caused by Colletotrichum species. JZUSB. 9 (10):764-778. 